\title{
Steering Towards Sustainability Requires More Ecological Restoration
}

\author{
James Aronson ${ }^{1,2 *} \&$ Sasha Alexander ${ }^{3}$
}

${ }^{1}$ Centre d'Ecologie Fonctionnelle et Evolutive, Centre National de la Recherche Scientifique, (UMR 5175), Montpellier, France

${ }^{2}$ Missouri Botanical Garden, St. Louis, MO, USA

${ }^{3}$ The University of Western Australia, Crawley, WA, Australia

\begin{abstract}
Ecological restoration of degraded ecosystems is now a global priority for addressing, and reconciling, environmental and sustainable development goals. Biocultural, bioregional, and landscape perspectives are vital for this purpose. Those working in restoration ecology, landscape ecology and conservation biology can help design, steer and implement such programs, but their work will only be effective if it is coordinated with ecological economics, law, and ethics. Many other disciplines and professions may be required as well, depending on the specific context. All scientists and professionals on a team must also be able to communicate and collaborate with non-scientists as well, including community leaders, NGOs, policymakers, landowners, and others. This is called transdisciplinarity. Here we discuss results obtained and outstanding challenges in this regard, in four landscape and bioregional scale restoration programs in South Africa, India, the USA, and Brazil. We also call for the establishment of an international network of long-term sites where research and development, capacity-building, workshops, outreach and in situ demonstration of ecological restoration, and the restoration of natural capital and ecosystem services, can all take place.
\end{abstract}

Key words: Restoration of Natural Capital, Networking, Working for Water, Lake Chilika, Puget Sound, Atlantic Forest Restoration Pact.

\section{Introduction}

In 2010, the U.N. Convention on Biological Diversity (CBD) launched the Aichi Biodiversity Targets for 2020, including Target 15 which calls for the restoration of at least $15 \%$ of all degraded ecosystems (CBD 2010). In 2011, the International Union for the Conservation of Nature (IUCN) and the German government launched the "Bonn Challenge" as a vehicle to help reach the CBD's targets and encourage global society to "[...] restore 150 million hectares of lost forests and degraded lands by 2020." (IUCN 2011). In October 2012, fourteen major international bodies, including the UNCCD and the UNFCCC, partnered with the governments of India, South Africa, and the Republic of Korea, to issue the Hyderabad Call for a Concerted Effort on Ecosystem Restoration (Aronson \& Alexander 2013). These initiatives explicitly recognize, and seek to operationalize, ecological restoration as a global priority for the recovery of biodiversity and critical ecosystem services. The Call

\footnotetext{
${ }^{\star}$ Send correspondence to: James Aronson

Centre d'Ecologie Fonctionnelle et Evolutive - CEFE, Centre National de la Recherche Scientifique - CNRS, UMR 5175, 1919

Route de Mende, 34293, Montpellier, France

E-mail: james.aronson@cefe.cnrs.fr
}

and other decisions of the Rio Conventions recognize that ecosystem and landscape restoration programs are vital bridge builders and catalysts to address their overlapping goals, namely: (i) to protect our most precious asset - biodiversity, (ii) to combat land degradation and desertification, while also addressing poverty reduction, social inequity, and sustainable development, and (iii) to mitigate and adapt to anthropogenic climate change.

As we seek to scale up restoration activities to meet the Hyderabad Call and Bonn Challenge, the participation of local stakeholders is key to the sustainability of restoration projects (Alexander et al. 2011; Brancalion et al. 2012, 2013a, 2013b). People understand and respond to the term "landscapes" much more than they do to "ecosystems". Hence the notion of biocultural restoration (Janzen 1988) is a vital correlate to ecological restoration along with a bioregional perspective. In layman's terms, this means getting local people - professionals and non-professionals alike - "on-board" and mainstreaming the concept and the process of restoration (Cowling et al. 2007). Another term that applies here is transdisciplinarity, i.e. scientists and professionals working together with stakeholders from all relevant social groups (Max-Neef 2005). Clearly, this is a key 
element in the search for sustainability (Brandt et al. 2013) and sustainability science (Kates et al. 2001; Weinstein \& Turner 2012). In practical terms, there is need for networks of long-term restoration sites in different biomes - to promote global solutions that are locally relevant.

Four examples of landscape or bioregional-scale projects from around the world help illustrate inter-linkages among landscape ecology, restoration ecology and conservation biology, on the one hand, with environmental law, economics and ethics on the other. Other fields and disciplines could be cited but we focus on these. We conclude with a call for the establishment of an international network of long-term biocultural restoration sites wherein comparative research and development, interdisciplinary workshops, outreach and in situ demonstration and capacity building can all take place.

\section{Restoring degraded ecosystems and the path towards sustainability}

The World Commission on Environment and Development (1987, p. 41) defines the term sustainability as “[... ] meet(ing) the needs of the present without compromising the ability of future generations to meet their own needs." The quest for sustainability requires the collaboration of landscape ecology, restoration ecology, and conservation biology so that distinct levels of ecological complexity (e.g. genes, species, populations, ecosystems, and landscapes) are understood and integrated - however imperfectly - into restoration planning and management frameworks at larger spatial scales (Lamb et al. 2005; Aronson \& Van Andel 2012; Clewell \& Aronson 2013). Those working in these disciplines will interact with hydrologists, microbiologists, geomorphologists, and other scientists, as well as professionals from other disciplines, in particular business, economics, human health, and social justice. Science and society must work together to navigate towards a relationship with our environment that is based on sustainability, rather than its opposite - inequitable economic growth for the few - with no regard for the rapid decline of all forms of natural capital and the growing divide between rich and poor (Aronson et al. 2007, 2010).

This vision is illustrated in Figure 1, which takes the form of a boat's wheel. By working and steering together, the six fields of research and practical application evoked here - among others - can help society see clearly as we steer towards a more sustainable and desirable future.

In the bottom half of Figure 1, we find environmental and ecological economics, environmental ethics, and law and governance. Though not illustrated in the Figure, public health, environmental education, anthropology, and other social sciences including traditional and indigenous knowledge, poverty alleviation, social justice, and sustainable rural development are implicit spokes on this wheel. Designers, artists and writers also have a role to play

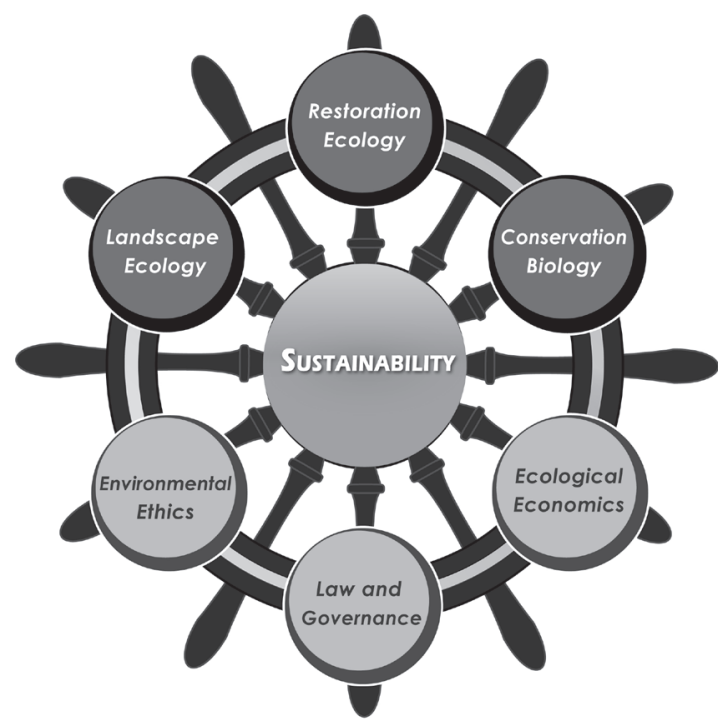

Figure 1. A metaphorical boat wheel showing six different disciplines working together to help steer society towards sustainability. Others are required as well, depending on the context.

in helping people re-connect to their landscapes and environment.

Bringing together individuals with training and experience in all these varied fields automatically broadens our perspectives on the role and implementation of ecological restoration in landscape or regional scale planning and management. It also improves and broadens the decision-making criteria and protocols not only for the management of terrestrial, and coastal ecosystems (Aronson et al. 2007), but also the deep sea (Van Dover et al. 2013).

Ideally, this process will build on 'bottom-up planning', based on the principle "[...] as much local as possible and only so much government regulation as necessary." (Berkes 2004, p. 626). In this spirit, Duff et al. (2009, p. 1135) have developed an Adaptive Collaborative Landscape Management (ACLM) process whereby "[...] research providers and users work closely together on projects to develop resources while adaptively managing to sustain or maintain landscapes in the long-term." But in very poor areas and countries, ACLM may simply not be possible as villagers and farmers live too close to the poverty line to take such risks that inevitably require high, up-front investments of time and resources. Only if outside funders step in, offering jobs, incentives or other opportunities can these ideas spark action on the ground. The case studies presented below provide some examples of lessons learned and outstanding challenges that still remain. One last 'spoke' to cite, when we seek to help steer societies towards sustainability, is developing a shared vocabulary (Aronson 2011) that translates across disciplines, and a negotiated set of values, priorities and vision for the future. In conjunction with maintenance of biodiversity - the living component of 
ecosystems - an obvious long-term objective of restoration is to augment, sustainably, the quality, quantity and flow of ecosystem services to human society (Bullock et al. 2011). Concurrently, conservation biology is required to elucidate the genetics, evolutionary, and population biology of the panoply of species necessary for the collaborative work of restoration scientists and practitioners (Maschinski 2006; Suding \& Leger 2012).

Landscape ecologists focus on spatial heterogeneity and ecological dynamics over a range of temporal scales, and across a wide range of ecosystems. Within landscape ecology, there has been a concerted effort towards its integration with sustainability science reconciling the competing need for both natural and multifunctional landscapes (Forman 1990; Naveh 2007; Wu 2010). This 'sister' discipline has served to guide restoration ecology as it broadens its spatial and conceptual scales (Aronson et al. 1993; Naveh 2004; Leite et al., 2013).

The landscape perspective helps large-scale restoration projects and programmes be more effective in achieving their objectives, including maintenance of biodiversity, enhancement of connectivity, and delivery of ecosystem services (Bell et al. 1997; Lovell \& Johnston 2009). This approach has resulted in opportunities for more-informed experimentation in restoration efforts and their integration at higher level spatial scales. Reinstating connectivity within narrow (e.g., rivers) or broad interfaces (e.g., estuaries) can help prioritize and inform ongoing restoration efforts (Beger et al. 2010). The concepts of landscape sustainability and landscape resilience are gaining acceptance among landscape ecologists, geographers, and architects (Wu 2013a), along with an emerging "landscape sustainability science" (Wu 2013b). The notion of forest and landscape restoration (FLR) has made great advances in recent years by explicitly recognizing the historical role of humans as actors in, and co-shapers of, their ancestral landscapes (Lamb et al. 2005; Mansourian et al. 2005; IUCN 2011).

From a combined ecological and economic perspective, the transition towards sustainability enables the restoration of functions and processes that enhance ecosystem integrity, productivity, and resilience in the face of unprecedented climate change and biodiversity loss. This includes restoring habitat for threatened populations and species vital to ecological processes while at the same time recovering the quality, quantity and flows of the full suite of ecosystem services. Finally, these objectives must be scaled up to restore functional diversity within landscapes and bioregions wherein ecosystems are interlinked and interdependent. This approach is aligned with the idea of restoring natural capital, which helps sum up all the ideas at issue here. Indeed, many of the current challenges in restoration ecology and the conservation sciences - could be neatly resolved with the broad concept of restoring natural capital, also known in the economics and public policy discourse as restoring ecological infrastructure (Neßhöver et al. 2011). Identifying natural capital as the target of our interventions and policy adjustments - that is, natural, semi-natural and multifunctional ecosystems, and their living components (i.e. biodiversity) - can help overcome the challenge of integrating various activities at the landscape scale and lead to more cost-effective restoration activities at the ecosystem scale.

\section{Case studies}

Let us now consider some examples of ongoing restoration projects across a range of historical, socio-economic and political contexts in South Africa, India, the USA, and Brazil. In each case, we will point out how the conceptual model of transdisciplinarity is being applied in large-scale restoration projects and discuss future challenges and opportunities for their further development within the broader search for sustainability.

\section{South Africa: Working for Water and Related Programs}

Eighteen years ago, South Africa initiated a national ecosystem restoration and job creation program called Working-for-Water (WfW), which could serve as a model for other developing countries and some industrialized countries (WfW 2013). Using restoration to address development issues, especially job creation as well as water supply and biodiversity conservation objectives, the South African government funded WfW to hire and train people to clear entire mountain catchments and large expanses of riparian zones of harmful alien invasive alien plants (IAPs). WfW also invests approximately 32 million Rand $(=3,765,000$ dollars) a year in biological control of all IAPs and is carefully studying the returns on investment (C. Marais, pers. comm., October, 2013).

The aim is to restore water supply, native biodiversity, and improve the livelihoods of the very poor. As hydrological processes are restored and the benefits become apparent, water utilities and municipalities as well as private landowners have begun contracting with the Department of Environmental Affairs' Natural Resource Management Programmes to begin the process of restoring ecosystems at the catchment or landscape scales.

Cullis et al. (2006) estimated that invasive alien trees congesting mountain catchments and riparian zones of South Africa were consuming more than 172 million cubic meters of water per year, which represented $4 \%$ of the registered total water use of the country. These authors estimated that if left unchecked, this biological invasion by terrestrial IAPs could ultimately lead to as much as $16 \%$ of the country's registered water use being siphoned off by them. As South Africa is a dry country, and water for agriculture, industry and domestic use is chronically in short supply, this restoration program, which increases ecosystem services related to water, holds great promise to foster sustainable development of societies and economies. 


\section{Lessons learnt and progress to date}

Through WfW and related programs, the South African government provides jobs and livelihoods for more than 40,000 people each year, mostly for the poorest, least educated people in the country. These interlinked programs thus address acute socio-economic concerns concurrently with long-term agricultural and environmental ones. The WfW model is being replicated in a variety of ecosystem restoration contexts and job creation programs, such as Working-for-Wetlands, Working-for-Woodlands, Wildlife Economy, Working-on-Fire and Working-for-Rivers (Giordano et al. 2012). All are public sector run and funded, with a broad team of scientists and professionals bringing diverse expertise from the social and environmental sectors and successfully working together to produce desired outcomes. In addition to restoring degraded ecosystems and maintaining intact ones (suppressing alien plant invasions and enhancing sustainable integrated veld and forest fire regimes), the project also helps restore social capital as people become more engaged and work to repair, recuperate and revitalize their heritage landscapes. Workers then help educate and inspire others in their communities based on what they have learned. In particular, the Working on Fire programme has been very successful in using programme beneficiaries to educate their home communities.

\section{Outstanding challenges that remain}

An obvious challenge for these South African programs lies in reconciling the needs and desires of diverse stakeholders, and balancing these trade-offs with ecological priorities of the larger society. An additional challenge is to find private, local government, and international investment for large-scale projects delivering such varied ecosystem services as water supply, carbon sequestration, biofuel production, habitat services for native biodiversity, and wildfire risk abatement. As beneficiaries and scale of delivery of services vary, so does the attractiveness for investment for each project and site.

An exciting new development is the land user incentive programmes which WfW contracts with community-based and other non-governmental entities representing land users and communities to carry out restoration work and maintain both restored and intact areas. The objective is to unlock private sector resources for the maintenance and restoration of natural resources. This can take the form of infrastructure, logistical support, equipment, management services and most importantly financial resources. It is hoped that new financial resources will be created for the programs through value-added industries, wherein cleared biomass from bush encroachment restoration and invasive plant clearing is marketed to the energy sector through a biomass to energy programme (C. Marais, pers. comm, October, 2013).
One of the aims of the land user incentives programme is to enhance buy-in by land users to improve sustainability, one of the major challenges to WfW. Once land has been cleared and restored, it needs to be maintained by the land user. If they do not buy into the restoration activities, there is a serious risk of the area being re-infested or degraded. By involving land users, getting them to allocate their own resources to the project, the risk of neglecting future maintenance work is minimized. Thus, the long-term challenge of affordability needs to be taken into account when designing a restoration project.

A further challenge is that of sustainable employment or decent jobs. At the moment, a very large percentage of WfW workers/beneficiaries are being employed by independent contractors on short-term contracts. During the 2012/13 financial year, the average WfW beneficiary was employed less than 70 days of the year. The target should be more than 100 days to get closer to a reliable and sustainable income for poor households. The land user incentives programmes are aimed at improving the average number of days of employment per individual per year. These programmes are all designed to draw the poorest of the poor at the entry level of the labor market. One would therefore expect a high level of turnover. This will be improved with the 3-year land user incentives agreements. Last but not least, there is a lack of management capacity amongst emerging contractors. By entering into longer term contracts there will be more time for the land user incentives programme to train emerging contractors.

Despite these shortcomings (Turpie et al. 2008), the WfW program provides valuable lessons for overcoming some of the conflicts that can arise when addressing complex economic, ecological and social issues, and the South African government is committed to learning from these and moving forward (Christo Marais, pers. comm. October, 2013). The pathbreaking WfW and associated programmes, and the many discussions and debates concerning them, across disciplines and sectors, are worthy of consideration elsewhere (Woodworth 2013).

\section{India: Chilika Lake, Orissa}

In 2002, the Chilika Development Authority (CDA) was awarded the Ramsar Wetland Conservation Award and Evian Special Prize (Ramsar Convention on Wetlands 2002) for its efforts to restore ecosystem and landscape services while fostering sustainable jobs and livelihoods in and around Chilika Lake. As one of Asia's largest brackish lagoons, it was previously threatened and resource-depleted primarily as a result of extensive siltation from catchments, the rapid spread of invasive species, and the expansion of aquaculture operations. After initial restoration activities proved effective, the condition of Chilika Lake and a large percentage of the Mahanadi river basin was considered as an exemplary Ramsar site (Ramsar Convention on Wetlands 2002). 
The basin comprises over 115,000 hectares of interconnected wetlands and terrestrial ecosystems that provide direct and indirect benefits to 0.2 million fishery workers and 0.4 million farmers living within the Mahanado Delta region. While the CDA and its partners continue to make advances towards their long-term restoration objectives of restoring hydrological functioning and habitats for native biodiversity and sustainable livelihoods, there are significant and continuing challenges in terms of governance, resource rights and local institutions.

\section{Lessons learnt and progress to date}

By far the most difficult and consequential intervention was restoring the salinity gradient within the lagoon by improving connectivity to the Bay of Bengal (Ghosh et al. 2006). Engaging stakeholders and local communities in decision-making process took time but was nonetheless critical to making progress. The recovery of water fluxes and subsequent increases in native biodiversity (e.g. waterbirds, dolphins), and fishery resources (e.g., fish, crustaceans, crabs), have helped reinstate community-led management through the revival of community fishing cooperatives, bird protection and watershed committees. Other positive impacts observed since the channel was dredged include an increase in salinity, reductions in the expansion of invasive species, and significant increases in the per capita income of the communities that depend on the lagoon (Kumar et al. 2011). Although the restoration at Lake Chilika resulted primarily from the success of hydrological modeling and ecological engineering, the Integrated Management Plan was developed with the assistance of biologists focused on avi- and aqua-fauna, restoration experts and landscape planners concerned with coastal ecosystem functioning and connectivity issues, and social scientists addressing local governance and management structures.

The restorative actions at Chilika Lake also contributed to the health and resilience of the river basin as a result of the inter-dependence of adjoining wetlands and other ecosystems that comprise the watershed. The lake is a vital link between freshwater and marine ecosystems. With the support of the Ramsar Convention on Wetlands and other global partners, the CDA was set up for the restoration and overall development of the lake. Beyond the restoration interventions and objectives already discussed, complementary efforts to promote sustainable development and biodiversity conservation are underway. These include participatory micro-watershed management, habitat protection, training programs for eco-tourism, and ferry services for isolated villages (CDA 2012). Like WfW in South Africa, the CDA community approach is unique in that it attempts to integrate ecological restoration and livelihood benfits which can help inform and inspire similar projects around the world.

\section{Outstanding challenges that remain}

The long-term success of restoration efforts at Lake Chilika will depend not only on the targeted delivery of ecosystem services -- from local provisioning and cultural services to regulating and supporting services of relevance at larger scales -- but also on the structures and mechanisms of resource allocation among stakeholders. Until 1991 and the advent of private leases to outsiders and non-fisherfolk, local communities enjoyed exclusive legal rights to their traditional fishing grounds, an institutional arrangement for resource management that fosters long-term sustainability (Ostrom 2005). These traditional resource management practices encouraged standards of behavior that maintain or improve social cohesion in the community (Sekhar 2007).

In the case of Lake Chilika, the establishment of a government-imposed lease system has led to a weakening of community property management institutions resulting in heightened tension and insecurity even as resource stocks have increased due to restoration efforts. In some instances, private leases have been granted to outsiders, and to the exclusion of local fisherfolk, merely to generate income for the government (Mishra \& Griffin 2010). The government sees this as part of its responsibility for regulating resource access in order to maintain the quality and quantity of ecosystem services, however it has failed to account for the impacts, both on-site and downstream, of a resource rights scheme that generates ecological conflict in the region, most of which relates to the growth of aquaculture.

This top-down approach to resource allocation and management threatens the traditional system of "capture fisheries" and the health of communities on and around the lake. Therefore, the long-term sustainability of aquatic resource management is also in danger as are the significant gains in the restoration of natural capital stocks afforded by this massive initiative. Restoring natural capital will not generate equitable benefits unless it is accompanied by good governance and strong local institutions.

\section{USA: Puget Sound, Washington}

The Puget Sound Nearshore Ecosystem Restoration Project (PSNERP) is one of the largest habitat and ecosystem restoration and preservation programs ever undertaken in the United States. It provides lessons for the entire bioregion, and demonstrates a promising approach to multi-scalar integration. The Puget Sound is part of a larger basin of inland marine waters that span the international boundary between Washington State, USA and British Columbia, Canada. It is home to over 1.6 million people, $70 \%$ of Washington's population and $77 \%$ of the state's total income is generated in the Puget Sound Basin (Harrison-Cox et al. 2012). A key challenge for the region is determining how to accommodate a doubling of the population by 2025 and to adapt to a changing climate, in the face of increasing pressures 
from land use changes, storm water, toxic pollution, and transportation infrastructure (PSP 2012).

Beginning in 2003, the Tacoma-based not-for-profit Earth Economics began conducting systematic ecosystem service valuation work in the Puget Sound region. Their 2010 study showed the asset value of marine and terrestrial ecosystems in the Puget Sound Basin to be hundreds of billions of dollars, with benefits provided to the regional economy calculated at between $\$ 9.7$ and $\$ 83$ billion per year (Harrison-Cox et al. 2012). Throughout the region, valuation results have become a regular catalyst of discussion and action in turn placing the restoration efforts in Puget Sound in an economic context.

Today many regional groups at the sub-watershed level are working to adopt ecosystem services in common decision-making frameworks with the explicit goal to secure political and public will and financial support for restoration funding. Diverse stakeholders in both highly urbanized and rural Puget Sound watersheds are defining restoration actions with an economic-based, multi-approach format which addresses salmon recovery, flood risk reduction, recreation, public health benefits and small forestry operations in upper watersheds.

\section{Lessons learnt and progress to date}

In contrast to the two previous examples cited above, the socio-ecological context in which the PSNERP project operates is in a highly urbanized and heterogeneous one, which means that the project's leaders and champions must find complementary solutions to achieve integration of social, cultural, political, legal, economic, and ecological goals and constraints. A change analysis geo-database and a variety of needs assessment frameworks were developed and, more recently, various strategies, design and feasibility reports which incorporated the finding of landscape ecologists, aquatic biologists and conservation biologists (PSNERP 2012). In 2013, Earth Economics began releasing a spatially explicit web-based database of ecosystem service values, the Ecosystem Valuation Toolkit (Earth Economics 2013). These tools have wider applicability and can assist with other large-scale estuarine restoration efforts, particularly those in areas with large urban populations.

The 2012 Action Agenda for Puget Sound focuses on the protection and restoration of freshwater, terrestrial, nearshore and marine ecosystems while reconciling land use change, stewardship in working landscapes, waterfront revitalization and climate protection (PSP 2012). Using science-based indicators, the restoration of rural and urban riparian areas is being targeted as this confers many benefits, such as the regulation of water temperature, salinity and pollution. These activities contribute significantly to the goal of restoring over 4,000 hectares of shellfish beds by 2020 . Conservation biologists are studying the genetic and functional traits of shellfish communities, while ecological economists are working to value ecosystem services of unique "feeder bluff" nearshore habitats (Flores et al. 2013) that provide sediment to beaches that are critical to all invertebrates. By comparing economic returns from restoration activities to more traditional built-infrastructure alternatives, such as installation of ecosystem-damaging bulkheads, policymakers, scientists and restoration professionals are helping to ensure policy decisions and fiscal investments that support the delivery of benefits such as provision of adequate habitat and food supplies for fish, crustaceans, reptiles, etc., including important recreational and commercial fisheries. Landscape ecologists help monitor progress in removing pollutants and the stabilization of sediments and shorelines in the face of sea level rise and storms. While the responsibility to future generations resonates very strongly with the residents of the Puget Sound (Stinchfield et al. 2009), restoration efforts have also been propelled by an integrated approach to watershed management that focuses on ecosystem services and their economic benefits.

Like Chilika Lake, in India, this case study illustrates a combined watershed/basin and production landscape approach, and highlights the challenges and opportunities for restoring connectivity at a bioregional scale. These studies demonstrate that landscape-scale restoration is not just about incorporating a hierarchical perspective and ecological networks framework but also about addressing the socio-economic, historical, political and cultural dimensions relevant to the project. This should remind us of the need for a "holistic approach" to ecological restoration (Clewell \& Aronson 2013) inspired by clear appreciation of the interrelationships between natural capital, ecosystem services and human wellbeing.

\section{Outstanding challenges that remain}

While ecosystem services are being applied more and more frequently in research, policy and planning activities, there remains a lack of funding opportunities to protect intact ecosystems through conservation easements or outright acquisitions. Studies have consistently shown that investments to protect healthy ecosystems are far more cost effective than investments to restore ecosystems that have been damaged (Harrison-Cox et al. 2012).

A challenge to funding ecosystem restoration activities in the context of Puget Sound is to conceive and enact a tiered taxing district system. Washington State law defines taxing districts with the power to impose tax burdens upon district property in proportion to property value, as opposed to obtaining revenue for public purposes in proportion to the benefits accruing to it (Revised Code of Washington 84.04.120). Taxing districts are classified into senior taxing districts (the state, the county, city or town, county road, port, and public utility districts) and junior taxing districts (conservation, stormwater, sewer, and shellfish districts). State law limits aggregate taxation of all taxing districts (not including the state) of $\$ 5.90 / \$ 1,000$ of 
assessed property value. When the cap is reached, junior districts go unfunded.

To address these challenges, Earth Economics has been working with the largest Puget Sound county to develop state legislation to enable the creation of a senior taxing district, the Watershed Investment District (King County 2013). A Watershed Investment District (WID) is an innovative institution that coordinates water-related investments in green and built infrastructure at the watershed scale to maximum public benefit at the lowest financial cost (Earth Economics 2010). A WID works with watershed partners to identify opportunities and challenges at the watershed-scale, coordinate diverse agencies and interests in the watershed, and fund the restoration, conservation and surface water management needs of the watershed. These include salmon habitat restoration, biodiversity, carbon sequestration, payments for ecosystem services schemes, ecosystem service markets, flood risk management, and storm water management.

\section{Brazil: Atlantic Forest Restoration Pact (AFRP)}

Only 12 percent of the Brazilian Atlantic forest remains today, concentrated primarily in hilly regions near the coast (Ribeiro et al. 2009). The littoral region, where the Atlantic forest once dominated now is home to 62 percent of the Brazilian population and 80 percent of its gross domestic product; pressures on the remaining forest, therefore, are very strong indeed (IBGE 2012). The Atlantic Forest Restoration Pact (AFRP) was launched in 2009 by a group of over 80 organizations, including NGOs, private companies, government agencies, private land owners, and research institutions. It is now seen as one of the most important and ambitious restoration programs in the world (http://www.pactomataatlantica. org.br/index.aspx?lang = en). The AFRP today includes 240 private, community, academic, and public members, and has as its mission to restore 15 million hectares of degraded lands (30\% of the pre-European conquest level) in the Brazilian Atlantic Forest by 2050 (Rodrigues et al. 2011; Calmon et al. 2011; Melo et al. 2013). Concurrently, it helps protect and connect, in a sustainable fashion, the remaining forest fragments. The strategy is to promote (1) biodiversity conservation; (2) job generation and income opportunities through the restoration supply chain; (3) provision of key ecosystem services to millions of people and businesses; and (4) establishing incentives, financial and otherwise, for landowners to comply with the Brazilian Forest Act (Tollefson 2011). Ecological restoration efforts are focused on re-establishing high-diversity tropical forests through various methods incorporating the sustainable harvesting of timber and non-timber forest products in areas that are under-going restoration, particularly in economically marginal agricultural areas (Rodrigues et al. 2011; Brancalion et al. 2012, 2013a, 2013b).
Thus, the vision is one of restoring natural capital, at landscape and bioregional or biome scales. Cultural ecosystem services, as well as the provisioning, regulating and supporting services, provide tangible and intangible benefits to society (Brancalion et al. 2013a). Through the restoration of 15 million hectares of degraded lands, the AFRP has the potential to generate more than 3 million direct and indirect local jobs through seed collection and processing, seedling production, planting, and maintenance, not to mention ongoing monitoring and evaluation, and basic and applied research. Moreover, it is expected that the 15 million hectares of restored forests will remove approximately 200 million tons of $\mathrm{CO}_{2}$ from the atmosphere per year and store more than 2 billion tons of $\mathrm{CO}_{2}$ by 2050 (Brancalion et al. 2013b). Given that recent research has shown that standing tropical forests represent $34 \%$ of global $\mathrm{CO}_{2}$ sequestration (Beer et al. 2010) and that restoration of such forests, their understory and soils has the capacity to store more $\mathrm{CO}_{2}$ than monocultures or mixed-species tree plantations (Kanowski \& Catterall 2010), the AFRP may significantly contribute to Brazil's reaching its commitment to reduce carbon emissions projected to 2020 by $36-39 \%$ (Brancalion et al. 2013b).

\section{Lessons learnt and progress to date}

One of the challenges is to avoid environmental setbacks in public policy and legal instruments, like those observed in the recent changes of the Brazilian Forest Act (see Garcia et al. 2013). All AFRP restoration initiatives are registered and available on their website. This online database includes key information such as project coordinates, total area being restored, restoration methodologies and techniques applied, partners and investors, total cost, monitoring standards, number of jobs created, and so on. This information could be used to promote the dissemination and exchange of experiences; develop capacity-building programs to improve and leverage existing efforts; attract investors and supporters to enhance the quality and scale of the restoration efforts; inspire others around the world; and promote ongoing research, training project development, and growth. The WfW program in South Africa and other government-funded restoration programs are curious to see how the private-public funding partnership of AFRP works, and adapt lessons from it. Further, the Brazilian laws requiring landowners to restore portions of their land is something that other countries could certainly profitably consider (Aronson et al. 2011).

\section{Outstanding challenges that remain}

The Brazilian Atlantic Forest Restoration Pact (AFRP), whilst very impressive, has a long way to go in achieving its targets and identifying the key barriers (e.g. legal, economic) to achieving greater success. Although there is a growing societal involvement for the promotion of large-scale restoration as means of improving human wellbeing and 
biodiversity conservation, some traditional agribusiness sectors are strongly engaged to avoid proactive policies that protect remaining forest cover and restore degraded farmlands. In addition, the AFRP has faced many barriers to transforming forest restoration into a more attractive activity for farmers. As a result, most restoration projects have been carried out exclusively in order to comply with laws, which undermines the potential to scale up restoration initiatives outside narrow strips of riparian buffers along water courses. Although there is much potential to transform forest restoration into an economically viable land use, it is essential to engage private landowners in restoration programs (see conceptual proposal in Brancalion et al. 2012). AFRP members still lack restoration models that would increase cost-effectiveness (i.e., reducing restoration costs and providing revenues by the exploitation of forest products and by Payment for Ecosystem Services schemes), governmental special policies for expanding and stimulating ecological restoration, attractive loans and financial incentives for entrepreneurs, weak juridical environment to support long-term investments in the forest economy, and strong extension agencies to disseminate these new restoration approaches among farmers and encourage their engagement. All these challenges were already identified by the AFRP direction board and the solutions needed to overcome these barriers are being developed by the AFRP working groups and members, but there is still a long way to success.

\section{Discussion and Conclusion}

The road to sustainability must cross three divides (Aronson et al. 2010), starting with the ideological divide between intransigent environmental activists, and some but not all "deep ecologists", on the one hand, and the most hardcore of "neoclassical" economists, who could well be called "deep economists". Then there is the economic divide between the rich and poor, both within and among countries, and finally the tragic information divide between 'the environment' and 'the market', which perversely blocks or fails to encourage the common-sense market adjustments needed in the face of dwindling resources, and above all biological limits to economic growth. Investing in restoring natural capital, we argue, can help overcome all three of these divides, but a steering wheel with solid and interconnected 'spokes' will be needed. The converging disciplines of landscape ecology, restoration ecology, and conservation biology are just such spokes, each with its special contribution to the task at hand. Hydrology, geomorphology, and restoration genetics are three more. Ecological engineering obviously has an important role to play both within larger restoration-oriented programmes and in the creation of ecosystems undertaken as part of compensation or offset schemes. Environmental law, governance, and politics, environmental ethics, and ecological and resource economics are also essential spokes of the steering wheel. Without legal frameworks and good governance, to provide and enforce incentives such as tax relief, and disincentives such pollution taxes, and other regulatory mechanisms, changes in behavior on the part of the public will be slow. To address the second divide, between rich and poor, strong national and international treaties are needed based on environmental, intergenerational, and social ethics, and a revamping of economic models to fully acknowledge the primordial value of natural capital as the basis for all human economies (Aronson et al. 2007).

A key challenge to be addressed by scientists and professionals who share this vision is to transcend our traditional biases, silos and habits of thinking, thereby fostering greater transdisciplinarity. In good measure, this requires overcoming the third divide related to environmental ethics. Demonstration and training sites are also needed to demonstrate the feasibility and multiple benefits of restoration. Additionally, the growing evidence (TEEB 2010, 2011; Neßhöver et al. 2011; De Groot et al. 2013) of the economic benefits of investing in ecological restoration should help overcome all three divides.

In the four case studies presented, transdisciplinarity has been used to good effect to increase and enhance natural capital as well as social capital, which adds up to biocultural restoration. Long-term, financial capital for society is augmented as well. Another example, somewhat similar to the AFRP and well worth considering, is the Fire Learning Network that focuses on 400,000 ha in western North America. This area is one where land ownership and management responsibilities are highly variable, and there is a very long history of political and resource use conflicts (Apostol \& Shlisky 2012). A Collaborative Forest Landscape Restoration (CFLR) Program was set up by the Congress of the U.S.A. under Title IV of the Omnibus Public Land Management Act of 2009. The goal is to encourage the collaborative, science-based restoration of priority forest landscapes that addresses human well-being as well as ecosystem restoration (http://www.fs.fed.us/restoration/ CFLRP/). This example, like the Puget Sound one, shows that regional scale restoration can work in industrialized countries as well as in developing and emerging countries like South Africa, India and Brazil. Yet in almost all countries there is a strong tendency for 'business as usual' to continue, and for culture-nature dynamics to continue 'as usual' as well. More detailed and comparative research and development, technology, documentation, capacity building, outreach and in-situ demonstration is required to prove that restoration on significant scales is feasible, and not a luxury but a necessity. If we choose to steer our societies towards a sustainable and desirable future, an interactive network of long-term restoration, ecosystem services and restoring natural capital sites, strategically located, would help jumpstart the process (Clewell \& Aronson 2013). Subsequently, long-term efforts could be anchored, and the steering of society could take a new course. As the world community of policy-makers, as exemplified in the three Rio Conventions, is now calling for large-scale restoration, we must continue to seek global solutions and approaches 
that are locally relevant. The concept of natural capital and ecosystem services are of great help. Restoration science and sustainability science are advancing. But there is no, and never will be, a one-size-fits-all recipe for ecological restoration, and even less so for biocultural restoration. Therefore we need to work together in self-organizing networks.

\section{Acknowledgements}

We are very grateful to Jean Paul Metzger, Jenifer Harrison-Cox, Christo Marais, Paddy Woodworth, Maria Nanette Roble and two anonymous reviewers for their time, and helpful comments, on the manuscript. We also warmly thank Jenifer Harrison-Cox, Pedro Brancalion, Christo Marais, Ritesh Kumar, as well as Mike Powell and James Blignaut, for providing information and reviewing the case studies. We thank Cyril Fédérico for redrawing Figure 1.

\section{References}

Alexander S et al., 2011. Opportunities and challenges for ecological restoration within REDD+. Restoration Ecology, 19:683-89. http://dx.doi. org/10.1111/j.1526-100X.2011.00822.x

Apostol D \& Shlisky A, 2012. Restoring Temperate Forests: A North American Perspective. In: Van Andel J \& Aronson J (eds.). Restoration Ecology: The New Frontier. 2nd ed. Oxford: Wiley-Blackwell. p. 161-172. http://dx.doi. org/10.1002/9781118223130.ch13

Aronson J, 2011. Sustainability science demands that we define our terms across diverse disciplines. Landscape Ecology, 26:457-460. http://dx.doi.org/10.1007/s10980-011-9586-2

Aronson J \& Van Andel J, 2012. Restoration ecology and the path to sustainability. In: Andel J \& Aronson J (eds.). Restoration Ecology: The New Frontier. 2nd ed. Oxford: Wiley-Blackwell. p. 293-304. http://dx.doi.org/10.1002/9781118223130.ch22

Aronson J \& Alexander S, 2013. Ecosystem Restoration is now a global priority: Time to roll up our sleeves. Restoration Ecology, 21. http://dx.doi.org/10.1111/rec.12011

Aronson J, Milton SJ \& Blignaut J (eds.), 2007. Restoring Natural Capital: Science, Business and Practice. Washington: Island Press.

Aronson J et al., 1993. Restoration and Rehabilitation of Degraded Ecosystems in Arid and Semi-Arid Lands. I. A View from the South. Restoration Ecology, 1: 8-17. http:// dx.doi.org/10.1111/j.1526-100X.1993.tb00004.x

Aronson J et al., 2010. The Road to Sustainability Must Bridge Three Great Divides. Annals of the New York Academy of Sciences, 1185:225-236. http://dx.doi. org/10.1111/j.1749-6632.2009.05281.x

Aronson J et al., 2011. What role should government regulation play in ecological restoration: Ongoing debate in São Paulo State, Brazil. Restoration Ecology 19:690-695. http://dx.doi. org/10.1111/j.1526-100X.2011.00815.x

Beer C et al., 2010. Terrestrial gross carbon dioxide uptake: global distribution and covariation with climate. Science,
329: 834-838. PMid:20603496. http://dx.doi.org/10.1126/ science. 1184984

Beger M et al., 2010. Conservation Planning for Connectivity across Marine, Freshwater, and Terrestrial Realms. Biological Conservation, 143:565-575. http://dx.doi.org/10.1016/j. biocon.2009.11.006

Bell SS, Fonseca MS \& Motten LB, 1997. Linking Restoration and Landscape Ecology. Restoration Ecology, 5:318-323. http://dx.doi.org/10.1046/j.1526-100X.1997.00545.x

Berkes F, 2004 Rethinking community-based conservation. Conservation Biology, 18:621-630. http://dx.doi. org/10.1111/j.1523-1739.2004.00077.x

Brancalion PHS et al., 2012. Finding the money for tropical forest restoration. Unasylva, 63:25-34.

Brancalion PHS et al., 2013a. Cultural ecosystem services and popular perceptions of the benefits of an ecological restoration project in the Brazilian Atlantic Forest. Restoration Ecology. http://dx.doi.org/10.1111/rec.12025

Brancalion PHS et al., 2013b. How to Organize a Large Scale Ecological Restoration Program? The Framework Developed by the Atlantic Forest Restoration Pact in Brazil. Journal of Sustainable Forestry. http://dx.doi.org/10.1080/105498 11.2013 .817339

Brandt S et al., 2013. A review of transdisciplinary research in sustainability science. Ecological Economics, 92:1-15. http:// dx.doi.org/10.1016/j.ecolecon.2013.04.008

Brazilian Institute of Geography and Statistics - IBGE, 2012. Available from: <www.ibge.gov.br>. Access in: 15 Oct 2013.

Bullock JM et al., 2011. Restoration of ecosystem services and biodiversity: conflicts and opportunities. Trends in Ecology \& Evolution, 26: 541-549. PMid:21782273. http://dx.doi. org/10.1016/j.tree.2011.06.011

Calmon $\mathrm{M}$ et al., 2011. Emerging threats and opportunities for large-scale ecological restoration in the Atlantic Forest of Brazil. Restoration Ecology, 19:154-158. http://dx.doi. org/10.1111/j.1526-100X.2011.00772.x

Chilika Development Authority - CDA, 2012. Eco-Restoration. Available from: $<$ http://www.chilika.com/eco_restoration. htm $>$. Access in: 15 Oct 2013.

Clewell AF \& Aronson J, 2013. Ecological Restoration: Principles, Values, and Structure of an Emerging Profession. 2nd Edition. Washington: Island Press. http://dx.doi. org/10.5822/978-1-59726-323-8

Convention on Biological Diversity - CBD, 2010. Global Biodiversity Outlook. Available from: $<$ https://www.cbd.int/ doc/gbo/gbo2/cbd-gbo2-en.pdf $>$. Access in: 15 Oct 2013.

Cowling RM, Pierce SM \& Sigwela AM, 2007. Mainstreaming the restoration of natural capital: A conceptual and operational framework. In: Aronson J, Milton SJ \& Blignaut J (eds.). Restoring Natural Capital: Science, Business and Practice. Washington: Island Press. p. 305-312.

Cullis JDS, Gorgens AHM \& Marais C, 2007. A strategic study of the impact of invasive alien plants in the high rainfall catchments and riparian zones of South Africa on total surface water yield. Water SA, 33: 35-42. 
De Groot R et al., 2013. Benefits of investing in ecosystem restoration. Conservation Biology. http://dx.doi.org/10.111/ cobi. 1215

Duff $\mathrm{G}$ et al., 2009. A collaborative design to adaptively manage for landscape sustainability in north Australia: lessons from a decade of cooperative research. Landscape Ecology, 24:1135-1143. http://dx.doi.org/10.1007/s10980-008-9236-5

Earth Economics, 2010. Toward Implementing the WRIA 9 Salmon Habitat Plan. Tacoma: Earth Economics.

Earth Economics, 2013. Ecosystem Valuation Toolkit (EVT). Available from: <http://esvaluation.org $>$. Access in: 15 Oct 2013.

Flores L et al., 2013. Policy Implications of the Economic Benefits of Feeder Bluffs and 12 Other Ecosystems in Clallam County. Tacoma, Washington: Earth Economics.

Forman RTT, 1990. Ecologically sustainable landscapes: The role of spatial configuration. In Zonneveld IS \& Forman RTT (eds.). Changing Landscapes: An Ecological Perspective. New York: Springer. p. 261-278. http://dx.doi. org/10.1007/978-1-4612-3304-6_14

Garcia LC et al., 2013. Restoration challenges and opportunities for increasing landscape connectivity under the new Brazilian Forest Act. Natureza \& Consevação, 11:181-185.

Ghosh AK, Pattnaik AK \& Ballatore TJ, 2006. Chilika Lagoon: Restoring ecological balance and livelihoods through re-salinization. Tokyo: Blackwell. p. 239-255.

Giordano T, Blignaut J \& Marais C, 2012. Natural resource management - an employment catalyst: The case of South Africa. Development Planning Division Working Paper Series no. 33. Development Bank of Southern Africa. Pretoria.

Harrison-Cox J et al., 2012. Puget Sound: Washington State's Best Investment. Tacoma, Washington: Earth Economics.

International Union for the Conservation of Nature - IUCN, 2011. Leaders define pathway to restoring 150 million hectares of lost forests. Available from: <http://www.iucn. org/media/news_releases/?8147/Leaders-define-pathwayto-restoring-150-million-hectares-of-lost-forests $>$. Access in: 15 Oct 2013.

Janzen DH, 1988. Tropical Ecological and Biocultural Restoration. Science, 239: 243-244. http://dx.doi.org/10.1126/ science.239.4837.243

Kanowski J \& Catterall CP, 2010. Carbon stocks in aboveground biomass of monoculture plantations, mixed species plantations and environmental restoration plantings in northeast Australia. Ecological Management \& Restoration, 11: 119-126. http://dx.doi.org/10.1111/j.1442-8903.2010.00529.x

Kates RW et al., 2001. Sustainability Science. Science, 292:641642. http://dx.doi.org/10.1126/science.1059386

King County, 2013. Watershed Investment Districts Draft Legislation. Available from: <http://www.govlink.org/ watersheds/9/plan-implementation/FundingMechanisms. aspx>. Access in: 15 Oct 2013.

Kumar R et al., 2011. Assessing wetland ecosystem services and poverty interlinkages: a general framework and case study. Hydrological Sciences Journal, 56:1602-1621. http:// dx.doi.org/10.1080/02626667.2011.631496
Lamb D, Erskine PD \& Parotta JA, 2005. Restoration of Degraded Tropical Forests. Science, 1628:310.

Leite MS et al., 2013. Landscape ecology perspective in restoration projects for biodiversity conservation: a review. Natureza \& Consevação, 11:108-118.

Lovell ST \& Johnston DM, 2009. Creating Multifunctional Landscapes: How Can the Field of Ecology Inform the Design of the Landscape? Frontiers in Ecology and the Environment, 7:212-220. http://dx.doi.org/10.1890/070178

Mansourian S, Vallauri D \& Dudley N (eds.), 2005. Forest Restoration in Landscapes: Beyond Planting Trees. New York: Springer.

Maschinski J, 2006. Implications of population dynamic and metapopulation theory for restoration. In: Falk DA, Palmer, MA \& Zedler JB (eds.). Foundations of Restoration Ecology. Washington: Island Press. p. 59-87.

Max-Neef MA, 2005. Foundations of transdisciplinarity Ecological Economics, 53:5-16. http://dx.doi.org/10.1016/j. ecolecon.2005.01.014

Melo FPL et al., 2013. Scaling-up tropical forest restoration in a biodiversity hotspot: lessons learned thus far. Environmental Science \& Policy. In press.

Mishra SR \& Griffin AL, 2010. Encroachment: A threat to resource sustainability in Chilika Lake, India. Applied Geography, 30: 448-459. http://dx.doi.org/10.1016/j. apgeog.2009.12.001

Naveh Z, 2005. Epilogue: Toward a Transdisciplinary Science of Ecological and Cultural Landscape Restoration. Restoration Ecology, 13: 228-234. http://dx.doi. org/10.1111/j.1526-100X.2005.00028.x

Naveh Z, 2007. Landscape ecology and sustainability. Landscape Ecology, 22:1437-1440. http://dx.doi.org/10.1007/ s10980-007-9171-x

Neßhöver C et al., 2011. Investing in Ecological Infrastructure. In: Ten Brink P (eds.).The Economics of Ecosystems and Biodiversity in National and International Policy Making. London and Washington: Earthscan. p. 401-448.

Ostrom E, 2005. A General Framework for Analyzing Sustainability of Socio-ecological Systems. Science, 325: 419-422. http://dx.doi.org/10.1126/science.1172133

Puget Sound Nearshore Ecosystem Restoration Project - PSNERP, 2012. Available from: <http://www. pugetsoundnearshore.org/index.html $>$. Access in: 15 Oct 2013.

Puget Sound Partnership - PSP, 2012. The 2012/2013 Action Agenda for Puget Sound. Washington State Government. Available from: <http://www.psp.wa.gov/downloads/ AA2011/083012_final/Action\%20Agenda\%20Book\%201_ Aug\%2029\%202012.pdf>. Access in: 15 Oct 2013.

Ramsar Convention on Wetlands, 2002. The Ramsar Wetland Conservation Award winners for 2002. Available from: <http://www.ramsar.org/cda/en/ramsaractivities-awards-2002-ramsar-wetland-16149/main/ ramsar/1-63-67-151\%5E16149_4000_0_>. Access in: 15 Oct 2013. 
Ribeiro MC et al., 2009. The Brazilian Atlantic Forest: How much is left, and how is the remaining forest distributed? Implications for conservation. Biological Conservation, 142: 1141-1153. http://dx.doi.org/10.1016/j.biocon.2009.02.021

Rodrigues RS et al., 2011. Large-scale ecological restoration of high-diversity tropical forests in SE Brazil. Forest Ecology and Management, 261:1605-1613. http://dx.doi.org/10.1016/j. foreco.2010.07.005

Sekhar NU, 2007. Social Capital and Fisheries Management: The Case of Chilika Lake in India. Environmental Management, 39:497-505. http://dx.doi.org/10.1007/s00267-006-0183-0

Stinchfield HM, Koontz L \& Sexton NR, 2009.Social and Economic Considerations for Coastal and Watershed Restoration in the Puget Sound, Washington: A Literature Review. Reston: US Geological Survey. Open-File Report 2009-1079. 78 p.

Suding K \& Leger E, 2012. Shifting Baselines: Dynamics of Evolution and Community Change in a Changing World. In: Van Andel J \& Aronson J (eds.). Restoration Ecology: The New Frontier. 2nd ed. Oxford: Wiley-Blackwell. p. 281-291. http://dx.doi.org/10.1002/9781118223130.ch21

TEEB, 2010. The Economics of Ecosystems and Biodiversity: Ecological and Economic Foundations. London, Washington: Earthscan.

TEEB, 2011. Investing in Ecological Infrastructure. In: Ten Brink P (ed.).The Economics of Ecosystems and Biodiversity in National and International Policy Making. London, Washington: Earthscan.

Tollefson J, 2011. Brazil revisits forest code. Nature, 476:259-260. http://dx.doi.org/10.1038/476259a
Turpie JK et al., 2008. The working for water programme, South Africa. Ecological Economics, 65:788-798. http:// dx.doi.org/10.1016/j.ecolecon.2007.12.024

Van Dover CL et al., 2013. Ecological Restoration in the Deep Sea: Desiderata. Marine Policy http://dx.doi.org/10.1016/j. marpol.2013.07.006

Weinstein M \& Turner E (eds.), 1992 Sustainability Science: Balancing Ecology and Economy. New York: Springer.

Woodworth P, 2013. Our once and future planet: Restoring the world in the Climate Changing Century. Chicago: University of Chicago Press. http://dx.doi.org/10.7208/ chicago/9780226081465.001.0001

Working for Water - WfW, 2013. Available from: <http://www. environment.gov.za/?q=content/projects_programmes/ workingforwater/index $>$. Access in: 15 Oct 2013.

World Commission on Environment and Development's (the Brundtland Commission) report Our Common Future, 1987. Oxford: Oxford University Press.

Wu J, 2010. Landscape of culture and culture of landscape: does landscape ecology need culture? Landscape Ecology, 25:1147-1150. http://dx.doi.org/10.1007/s10980-010-9524-8

$\mathrm{Wu}$ J, 2013a. Key concepts and research topics in landscape ecology revisited: 30 years after the Allerton Park workshop. Landscape Ecology, 20:1-11. http://dx.doi.org/10.1007/ s10980-012-9836-y

Wu J, 2013b. Landscape sustainability science: Ecosystem services and human well-being in changing landscapes. Landscape Ecology, 28:999-1023. http://dx.doi.org/10.1007/ s10980-013-9894-9

Received: March 2013

First Decision: May 2013

Accepted: October 2013 